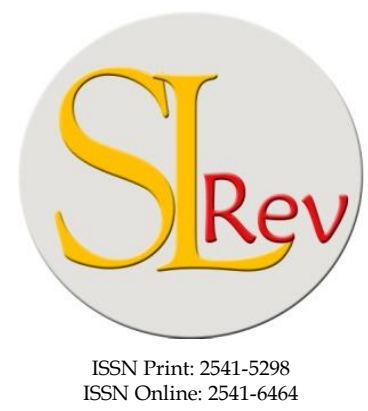

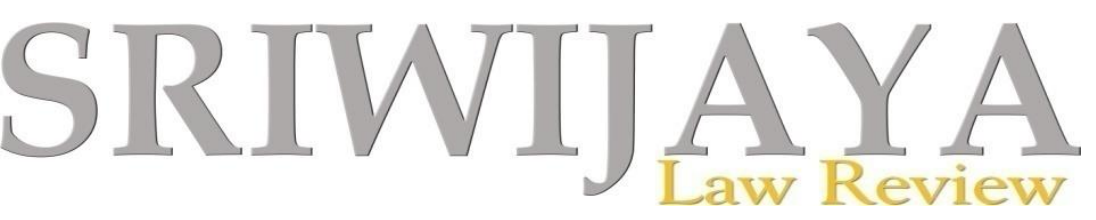

Editorial Office: Faculty of Law, Sriwijaya University, Jalan Srijaya Negara,

Palembang, South Sumatra 30139, Indonesia.

Phone: +62711-580063Fax: +62711-581179

E-mail: sriwijayalawreview@unsri.ac.id| sriwijayalawreview@gmail.com

Website: http://journal.fh.unsri.ac.id/index.php/sriwijayalawreview

\title{
Unilateral Claim in Dispute of Island Over the South China Sea
}

\author{
Muhammad Nasir, ${ }^{\mathrm{a}}$ Wan Siti Adibah Wan Dahalan, ${ }^{\mathrm{b}}$ Harun, ${ }^{\mathrm{a}}$ and Phoenna Ath Thariq ${ }^{\mathrm{c}}$ \\ Faculty of Law, Malikussaleh University, Indonesia. Email: muhammadnasir@unimal.ac.id \\ Faculty of Law, National University of Malaysia, Malaysia. Email: wsa@ukm.edu.my \\ Department of Law, Teuku Umar Univesity, Indonesia. Email: phoennaaththariq@utu.ac.id
}

\begin{tabular}{|c|c|}
\hline Article & Abstract \\
\hline $\begin{array}{l}\text { Article History } \\
\text { Received: Des 20, 2018; } \\
\text { Reviewed: Jan 13, 2020; } \\
\text { Accepted: Jan 28, 2020; } \\
\text { Published: Jan 31, } 2020 .\end{array}$ & $\begin{array}{l}\text { In the unilateral claim, every determination of a territory is the right of a } \\
\text { sovereign state and does not require agreement with international } \\
\text { organizations or other countries. Especially regarding the borders of a } \\
\text { country, many international regulations require a joint determination } \\
\text { (bilateral or multilateral). The norm will impact the absence of responses } \\
\text { from another country, or such a country does not react because its interests } \\
\text { were not disturbed. China's unilateral statement over the South China Sea } \\
\text { has tried to dominate globally, and at the same time, there has been no } \\
\text { stabilization of peace. It will likely continue, expand, and have long-term } \\
\text { adverse impacts on the regional economic and security situation in the } \\
\text { region. China's unilateral claims in the South China Sea have also resulted } \\
\text { in other warring countries, strengthening their presence and claims. This } \\
\text { research uses normative approach which examines the unilateral claims } \\
\text { under international law in the South China Sea especially in the UNCLOS } \\
1982 \text { and other related international law instruments. As a result, for } \\
\text { China, it is necessary to improve its current position, at least it needs to } \\
\text { negotiate in the future. Countries which is involved in the South China Sea } \\
\text { should clarify and submit territorial claims and maritime rights under } \\
\text { international law, including the UNCLOS } 1982 \text {. }\end{array}$ \\
\hline \multicolumn{2}{|c|}{$\begin{array}{l}\text { (C2020. This article is an Open Access Research distributed under the term of the Creative Commons } \\
\text { Attribution License (https://creativecommons.org/licences/by/4.0), which permits unrestricted use, } \\
\text { distribution, and reproduction in any medium, provided the original works is properly cited. }\end{array}$} \\
\hline
\end{tabular}

\section{INTRODUCTION}

Conflicts in the South China Sea still occur. ${ }^{1}$ The South China Sea is an area of economic, political, and strategic value. ${ }^{2}$ This area is critical because it is a navigation area for merchant

1 Nicole Jenne, "Managing Territorial Disputes in Southeast Asia: Is There More than the South China Sea?," Journal of Current Southeast Asian Affairs 36, no. 3 (2017): 35-61.

2 Arief Bakhtiar Darmawan \& Lady Mahendra, "Isu Laut Tiongkok Selatan: Negara-Negara ASEAN Terbelah Menghadapi Tiongkok," Global \& Strategis 12, no. 1 (2018): 79-85, https://ejournal.unair.ac.id/JGS/issue/view/735. 
ships, and gas and oil-carrying ships, and it has natural oil and gas sources. The South China Sea has a wealth of seabed and has the potential to generate cooperation between countries and, at the same time, can invite conflicts. For decades China, Malaysia, Vietnam, Brunei, the Philippines, and Taiwan have been involved in disputes over the region. In addition to these countries, there are also other countries outside the South China Sea region involved in this dispute, namely the United States, Japan, and Russia. ${ }^{3}$ The conflict in the South China Sea covers the issue of sovereignty over the islands, also including the issue of sovereignty over the continental shelf and Exclusive Economic Zone (EEZ). These problems include political issues, international maritime law, as well as the problem of using the latest exploration technology on the seabed.

The South China Sea is a semi-enclosed sea containing potentially extensive sources ${ }^{4}$ Whoever controls the South China Sea is expected to master all the primary resources there. ${ }^{5}$ China, Malaysia, Vietnam, the Philippines, Brunei, and Taiwan are always competing to assert their sovereignty. The South China Sea borders China and Taiwan to the north, while in the west to the south, it borders Vietnam, Kemboja, Thailand, and western Malaysia. The eastern part is bordered by the Philippines, and the southern part is bordered by Indonesia and eastern Malaysia. ${ }^{6}$

The potential and economic interests in the South China Sea are based on fish, oil, and gas, even though it is estimated that the South China Sea also has minerals. ${ }^{7}$ The South China Sea floor consists of 1.7 million $\mathrm{km}^{2}$ of the continental shelf, which has a depth of fewer than 200 meters and 2.3 million $\mathrm{km}^{2}$ from the seafloor deeper than 200 meters. The seabed includes the continental shelf mainly in the western and southern parts, while the deeper parts in some places reach more than 500 meters. ${ }^{8}$

China put forward its claims based on history, ancient documents, maps, and relics left by fishermen since 2000 years ago. For China, the Spratly Islands, which are part of the South China Sea, have been part of China since the Han, Yuan, and Ming dynasties. In addition, China also referred to a border agreement between China and France in 1887. The same period Vietnam became a French colony where the Paracel Islands and the Spratly Islands were handed over to China. ${ }^{9}$ In 1930 France had occupied one of the Spratly Islands, and in 1931 France sent a note to the Chinese Embassy in Paris, claiming Vietnam's sovereignty over the Spratly Islands and the Paracel Islands, which China later denied. Regardless of this rebuttal, France occupied the Spratly Islands and Pulau Aba and declared the islands part of the kingdom of Vietnam from 1933 to 1939. Japan then replaced France to occupy the Spratly

3 JR Larry W. Coker, The Spratly Islands Dispute: Can ASEAN Provide the Framework For A Solution? (U.S. Army War College Carlisle Barracks, Pennsylvania, 1996).

4 Christopher Linebaugh, "Joint Development in a Semi-Enclosed Sea: China's Duty to Cooperate in Developing the Natural Resources of the South China Sea," Columbia Journal Of Transnational Law, 52, no. 2 (2014): 542-46.

5 Linebaugh.

6 Asnani Usman and Rizal Sukma, Konflik Laut China Selatan Tantangan Bagi ASEAN (Jakarta: Center For Strategic and International Studies, 1997).

7 Nong Hong, UNCLOS and Ocean Dispute Settlement: Law and Politics in the South China Sea (USA and Canada: Routledge is an imprint of the Taylor \& Francis Group, 2012).

8 Hasjim Djalal dalam Asnani Usman dan Rizal Sukma, Konflik Laut China Selatan Tantangan Bagi ASEAN (Jakarta: Center For Strategic and International Studies, 1997).

9 Usman and Sukma, Konflik Laut China Selatan Tantangan Bagi ASEAN. 
Islands from 1939 to $1945 .{ }^{10}$ After Japan lost the War World II in 1945, France again occupied the Spratly Islands in 1946. China again denied the actions of France and a month later sent troops with warships to occupy the Spratly Islands. In 1947, China put the Spratly islands under its sovereignty as part of the Guangdong region. ${ }^{11}$

In short, in recent months, China's unilateral actions stating its claims in the South China Sea have pushed new tensions at the regional level. ${ }^{12}$ China's unilateral action in the South China Sea, ${ }^{13}$ including island sovereignty claims from the past to the present by reclaiming human-made islands in the Spratly Islands and Paracels Islands, expanding airports and distributing military forces, is not a good sign for the settlement of disputes peacefully in the South China Sea. It is because Malaysia, Brunei, Vietnam, Malaysia, the Philippines, and Taiwan are also countries that claim the region. ${ }^{14}$ In fact, these countries strengthen their presence and claims.

The unilateral statement of China's sovereignty over the South China Sea for global power has harmed countries in the region. If the conflict occurs, it will likely continue, expand, and have long-term adverse impacts on the regional economic and security situation in the region. China itself will be affected by almost 80 percent of its oil imports, and most of its goods, imports and exports, flow through the Malacca Strait and the South China Sea. China's claims of unilateral sovereignty over the South China Sea have made a majority of Chinese people mistakenly believe that China has the whole South China Sea ${ }^{15}$ and this will harm other neighboring countries. Therefore, it is necessary to examine further how the position of the unilateral claim in China's claims in the South China Sea region is in the perspective of international law.

\section{RESEARCH METHODS}

This study uses a normative approach method ${ }^{16}$ carried out through library studies, namely the study of library materials. The normative approach also examines the legal history, the comparison of law, and the philosophy of law. Legal research is a new, thorough, systematic study and research on the facts of data or concepts theorized on specific legal issues, principles, and regulations to ensure information to make discoveries and improve these concepts, theories, principles, and uses. ${ }^{17}$ Therefore, this study begins by first examining the unilateral claims under international law in the South China Sea, reviewing the concept of the unilateral claim according to international law so that a conclusion as the result of this study can be found.

10 Usman and Sukma.

11 Kuo-hsing Chi, The Spratlys Disputes and Prospects for Settlement/Ji Guoxing (Kuala Lumpur, Malaysia: Institute of Strategic and International Studies, 1992).

12 Yun Sun, "China's New Calculations in the South China Sea," Asia Pacific Bulletin, 2014, https://www.eastwestcenter.org/sites/default/files/private/apb_267_0.pdf.

13 Hong, UNCLOS, and Ocean Dispute Settlement: Law and Politics in the South China Sea.

14 Marius Grinius, South China Sea, and the New Great Game (Canadian Global Affairs Institute, 2016).

15 Hoang Anh Tuan, "Chinese Strategic Miscalculations in the South China Sea," Asia Pacific Bulletin, 2012, https://www.eastwestcenter.org/sites/default/files/private/apb_181.pdf.

16 A. Yakin, Legal Research and Writing (Lexis Nexis, Kelana Jaya, 1992).

17 Mahdi Zahraa, Research Methods for Law Postgraduate Overseas Student (Stiglow Sdn. Bhd. Kuala Lumpur, 1998). 


\section{THE CONCEPT OF UNILATERAL CLAIM IN INTERNATIONAL LAW}

At present, there is no formal definition of unilateralism in international law. Similarly, no agreement defines unilateralism as a general legal concept, and no definition includes everything in customary international law. ${ }^{18}$ However, some experts provide their definitions according to the research that has been done.

According to Weingerl, declaring state actions as unilateral are international legal transactions (state actions that are permitted), which represent legally recognized ways to realize (or express) unilateral agreements to be bound (precipitating conduct) and create, modify, suspend or terminate rights and international obligations in accordance with international law. ${ }^{19}$ Unilateralism is an agenda or one that supports a unilateral action. Such actions can arise because they do not like other parties or opponents as a form of commitment to achieve goals agreed by all parties. Unilateralism is implemented when it is the most efficient solution, meaning that Unilateralism is used in terms of issues that can be resolved without cooperation. However, the government also has a choice between unilateralism or multilateralism to avoid policies that cannot be realized in a unilateral way or fight for multilateral solutions to problems that should be resolved unilaterally. ${ }^{20}$

In other words, unilateral actions are interpreted as one-party action carried out by a country to cause legal consequences. For example, several Indonesian policies regarding the act of unilateralism have been carried out since 1957. Some Indonesian policies in this era were full of resistance to international law. In 1957, Indonesia's disillusionment with the United Nations was heightened because the UN was deemed no longer helping Indonesia in a dispute with the Netherlands over West Irian so that in 1958 Indonesia issued government regulation (PP) No. 23 of 1958 which nationalized all Dutch companies in Indonesia. Based on the explanation of this $\mathrm{PP}$, this policy was taken in order to save the continuity and smoothness of the economy due to the struggle for the liberation of West Irian. This nationalization policy has caused controversy and produced a lawsuit against Indonesia in a German court. International law experts also spoke out criticizing this policy as a violation of international law. International legal expert Mochtar Kusumaatmadja himself acknowledged that this policy was contrary to international law concerning the protection of foreigners and their property. Indonesia's resistance to international law peaked at the time of the emergence of strategic threats caused by the law of the sea at that time. The width of the sea, which is only allowed 3 miles has resulted in Indonesia being separated by the free sea and open space for the freedom of Dutch warships amid the struggle for West Irian. As a result, Indonesia saw that the prevailing marine law at that time was very detrimental to the survival of Indonesia because the territory of Indonesia had been scattered and was very vulnerable to disintegration by regions which at that time tended to strengthen. This threat raises issues of

\footnotetext{
18 Ales Weingerl, "Definition of Unilateral Acts of States," n.d., http://www.esilsedi.eu/sites/default/files/Weingerl_0.PDF.

19 Weingerl.

20 Aris Kurniawan, "Pengertian Hubungan Bilateral, Multilateral Dan Unilateral Beserta Contohnya," Gurupendidikan.com, 2019, http://www.gurupendidikan.co.id/pengertian-hubungan-bilateral-multilateraldan-unilateral-beserta-contohnya/.
} 
national resilience and security and rapidly increases the negative sentiment that international law is unfair. ${ }^{21}$

As a reaction to the injustice of the law of the sea, then in 1957, Indonesia issued a unilateral declaration famously known as the Djuanda Declaration. This declaration affirms that the sea between islands is the one that connects islands rather than separating them. For this reason, the declaration stipulates a straight baseline drawing that connects the outermost points of the outer islands and subsequently claims that the waters inside it are originally the free sea into inland waters. This declaration indeed invited loud protests from Western countries, especially the United States, which considered this declaration as a violation of international law. Although this declaration was rejected at the 1958 Geneva Conference on Law of the Sea, Indonesia remained adamant with this policy by issuing Law No. 4 of 1960 which maintained a 'persistent non-compliance' attitude towards 'international law,' until finally this idea was accepted at the 1982 UN Convention on the Law of the Sea. ${ }^{22}$

\section{CHINESE UNILATERALISM IN SOUTH CHINA SEA}

China has claimed the Paracel Islands in the North and the Spratly Islands in the South of the South China Sea. The claim is based on history, according to China's interests. It was found from several sources that China's presence in the Spratly Islands has begun since the 19th century. ${ }^{23}$ From 1876 to 1877 , the Paracel Islands were Chinese property and demands against the Spratly Islands in 1883. In 1887, a border agreement between France and China was intended to encompass all islands. However, China does not name the island as its own, while France claims that the agreement only covers the northern part of the South China Sea. ${ }^{24}$

However, many Chinese writers argue that China fulfilled the conditions with the impression of carrying out sovereignty over small islands, except for the Spratly Islands for centuries until finally, France annexed the islands and the islands of the China Sea in 1933. ${ }^{25}$ South is part of French waters. ${ }^{26}$ However, China considered having power over the islands until the end of World War II. ${ }^{27}$ In addition to taking unilateral action to change the status quo, China also strengthened its argument on its controversial "nine-dash line" in the South China Sea, which has shown a clear indication of China's determination to uphold its controversial claims. China's foreign policy has still debated the validity of the nine-dash line,

21 Damos Sumoli Agusman, "Indonesia Dan Hukum Internasional: Dinamika Posisi Indonesia Terhadap Hukum Internasional,” Jurnal Opinion Juris 15, no. Januari-April (2014): 15-16.

22 Agusman.

23 Jon M. Van Dyke and Noel A. Ludwig Mark J. Valencia, Sharing the Resources of the SCS, Martinus Nijhoff Publishers, 1997), Hlm. 21; Lihat Juga: Hong, Nong, UNCLOS, and Ocean Dispute Settlement: Law and Politics in the South China Sea (Routledge. Abingdon. Oxon [UK], 2012).

24 Chi-kin Lo, "China's Policy Towards Territorial Disputes: The Case of the South China Sea Islands," Etudes Internationales 22, no. 3 (1991).

25 Jiang Liand Zhang Jie, 2010, "The Application of Archipelagic Principles and Delimitation of the South China Sea", China Oceans Law Review, No. 1, p. 159; Lewis M. Alexander, 1987, "Uncertainties in the Aftermath of UNCLOS III: The Case for Navigational Freedoms", Ocean Development \& International Law, Vol. 18, Issue 3, p. 336; See, e.g., Ji Guoxing, The Spratlys Disputes and prospects for Settlements (ISIS, Malaysia, 1992); Teh-Kuang Chang, "China 's Claim of Sovereignty over Spratly and Paracel Islands: A Historical and Legal Perspective," Case Western Reserve Journal of International Law 23, no. 3 (1991): 399.

26 Hong, UNCLOS and Ocean Dispute Settlement: Law and Politics in the South China Sea.

27 Mark J. Valencia, Sharing the Resources of the SCS, Martinus Nijhoff Publishers, 1997), Hlm. 21; Lihat Juga: Hong, Nong, UNCLOS, and Ocean Dispute Settlement: Law and Politics in the South China Sea. 
and now Chinese analysts unanimously deny that China has unilaterally referred to the controversial claim. ${ }^{28}$ At least there are three unilateral actions of China in the South China Sea, which are:

1. China has disrupted Vietnamese and Philippine fishing vessels in the EEZ that have been overlapped.

2. China is developing a continental shelf that is within 200 miles of the coastline of Vietnam. ${ }^{29}$

3. China has also built artificial islands that have been filled in the Spratly Islands, namely Johnson South Reef, Gaven Reef, Hughes Reef, Cuarteron Reef, and Fiery Cross Reef. ${ }^{30}$

China's unilateral claims have resulted in other warring countries strengthening their presence and claims. Therefore, for China, it is necessary to improve its current position, at least it needs to negotiate in the future. China prefers to use a civilian and military approach but does not refuse military coercion if necessary. ${ }^{31}$ In China's understanding, the nine broken lines have strengthened China's position historically. Some Chinese experts have found justification within UNCLOS itself, claiming that the agreement was "ambiguous" and "unconvincing" on historical issues. ${ }^{32}$

Therefore, in their view, the issue of historical rights was not resolved by UNCLOS. Instead, they tried to explore alternative justifications for UNCLOS, namely through other international custom laws. Hence, it is not excessive if China has used unilateral claims to overcome this problem. Some of the rights and responsibilities of countries should be regulated in article 74 (1) and Article 83 (1) UNCLOS 1982. For example, in Article 74(1) UNCLOS 1982, namely: Determination of the boundaries of exclusive economic zones between countries whose beaches are facing each other or situated side by side must be held with an agreement on the basis of international law, as stipulated in Article 38 of the Status of the International Court, to achieve a fair solution. Meanwhile, in Article 83 (3) it is stated that the determination of the continental shelf boundary between countries whose beaches are facing each other or situated side by side must be carried out with an agreement on the basis of international law, as stated in Article 38 of the Statute of the International Court to achieve a fair settlement.

China's statement on unilateral sovereignty over the South China Sea has taken place to dominate globally, and at the same time, there has been no stable global peace. If the conflict breaks out, it will likely continue, expand, and have long-term adverse impacts on the regional economic and security situation in the region. China itself will be affected because nearly 80

28 Sun, "China's New Calculations in the South China Sea."

29 Yurika Ishii, "International Territorial Disputes And Confrontations In The South China Sea From A Legal Perspective," in The 18th Japan-EU Conference, Standards, Governance and the Rule of Law: Opportunities for EU-Japan Cooperation (Brussel, 2015).

30 Mary Fides A. Quintos, "Artificial Islands in the South China Sea and Their Impact on Regional (In)Security,” FSI Insight II, no. 2 (2015): 1, http://www.fsi.gov.ph/wp-content/uploads/2015/03/2015-0305Vol-2-No-2-FSI-Insights-Artificial-Islands-in-the-South-China-Sea-Quintos.pdf.

31 Sun, "China's New Calculations in the South China Sea."

32 Sun. 
percent of its oil imports and most of its goods, imports and exports, flow through the Malacca Strait and the South China Sea. ${ }^{33}$

Challenges from other countries are also one of the factors that weakens China's claims. At this time, the Philippines, Malaysia, Brunei, and Vietnam, had basic demands on all or part of these islands. They expressed strong resistance to unilateral actions that could change the status quo in the South China Sea. The Philippines, Malaysia, and Brunei and Vietnam also expressed strong concern over the current situation in the South China Sea. They repeated their strong opposition to coercion or unilateral action that could change the status quo in the South China Sea. Furthermore, asking for all restraint, taking steps to ease tension and refrain from provocative actions that can increase tension. ${ }^{34}$

\section{CONCLUSION}

Unilateralism is an agenda that supports a unilateral action. Such actions can arise because they do not like other parties or opponents as a form of commitment to achieve goals agreed by all parties. Unilateralism is implemented when unilateralism is the most efficient solution, meaning that Unilateralism is used in terms of issues that can be resolved without cooperation.

China's statement on unilateral sovereignty over the South China Sea has sought to dominate globally, and at the same time, there has been no stable global peace. If the conflict breaks out, it will likely continue, expand, and have long-term adverse impacts on the regional economic and security situation in the region. China's unilateral claims in the South China Sea have also resulted in other warring countries strengthening their presence and claims. Therefore, for China, it is necessary to improve its current position, at least that it needs to negotiate in the future. Countries involved in the South China Sea should clarify and submit territorial claims and maritime rights under international law, including the UN Convention on the Law of the Sea (UNCLOS). In this case, they support the right of the countries involved to try to resolve the dispute peacefully, including through arbitration. UNCLOS 1982 also regulates the rights and obligations of the state in claiming its maritime territory.

\section{REFERENCES}

Agusman, Damos Sumoli. "Indonesia Dan Hukum Internasional: Dinamika Posisi Indonesia Terhadap Hukum Internasional.” Jurnal Opinion Juris 15, no. Januari-April (2014): 1516.

Chang, Teh-Kuang. "China 's Claim of Sovereignty over Spratly and Paracel Islands: A Historical and Legal Perspective." Case Western Reserve Journal of International Law 23, no. 3 (1991): 399.

Chi, Kuo-hsing. The Spratlys Disputes and Prospects for Settlement/Ji Guoxing. Kuala Lumpur, Malaysia: Institute of Strategic and International Studies, 1992.

Grinius, Marius. South China Sea and the New Great Game. Canadian Global Affairs Institute, 2016.

33 Tuan, "Chinese Strategic Miscalculations in the South China Sea."

34 Sun, "China's New Calculations in the South China Sea." 
Hong, Nong. UNCLOS and Ocean Dispute Settlement: Law and Politics in the South China Sea. USA and Canada: Routledge is an imprint of the Taylor \& Francis Group, 2012.

Ishii, Yurika. "International Territorial Disputes And Confrontations In The South China Sea From A Legal Perspective." In The 18th Japan-EU Conference, Standards, Governance and the Rule of Law: Opportunities for EU-Japan Cooperation. Brussel, 2015.

Jenne, Nicole. "Managing Territorial Disputes in Southeast Asia: Is There More than the South China Sea?” Journal of Current Southeast Asian Affairs 36, no. 3 (2017): 35-61.

Kurniawan, Aris. "Pengertian Hubungan Bilateral, Multilateral Dan Unilateral Beserta Contohnya." Gurupendidikan.com, 2019. http://www.gurupendidikan.co.id/pengertianhubungan-bilateral-multilateral-dan-unilateral-beserta-contohnya/.

Larry W. Coker, JR. The Spratly Islands Dispute: Can ASEAN Provide the Framework For A Solution? U.S. Army War College Carlisle Barracks, Pennsylvania, 1996.

Linebaugh, Christopher. "Joint Development in a Semi-Enclosed Sea: China's Duty to Cooperate in Developing the Natural Resources of the South China Sea." Columbia Journal Of Transnational Law, 52, no. 2 (2014): 542-46.

Lo, Chi-kin. "China's Policy Towards Territorial Disputes: The Case of the South China Sea Islands." Etudes Internationales 22, no. 3 (1991).

Mahendra, Arief Bakhtiar Darmawan \& Lady. "Isu Laut Tiongkok Selatan: Negara-Negara ASEAN Terbelah Menghadapi Tiongkok." Global \& Strategis 12, no. 1 (2018): 79-85. https://e-journal.unair.ac.id/JGS/issue/view/735.

Mark J. Valencia, Jon M. Van Dyke and Noel A. Ludwig. Sharing the Resources of the SCS, Martinus Nijhoff Publishers, 1997), Hlm. 21; Lihat Juga: Hong, Nong, UNCLOS and Ocean Dispute Settlement: Law and Politics in the South China Sea. Routledge. Abingdon. Oxon [UK], 2012.

Quintos, Mary Fides A. "Artificial Islands in the South China Sea and Their Impact on Regional (In)Security." FSI Insight II, no. 2 (2015): 1. http://www.fsi.gov.ph/wpcontent/uploads/2015/03/2015-0305-Vol-2-No-2-FSI-Insights-Artificial-Islands-in-theSouth-China-Sea-Quintos.pdf.

Sukma, Hasjim Djalal dalam Asnani Usman dan Rizal. Konflik Laut China Selatan Tantangan Bagi ASEAN. Jakarta: Center For Strategic and International Studies, 1997.

Sun, Yun. "China's New Calculations in the South China Sea." Asia Pacific Bulletin, 2014. https://www.eastwestcenter.org/sites/default/files/private/apb_267_0.pdf.

Tuan, Hoang Anh. "Chinese Strategic Miscalculations in the South China Sea." Asia Pacific Bulletin, 2012. https://www.eastwestcenter.org/sites/default/files/private/apb_181.pdf.

Usman, Asnani, and Rizal Sukma. Konflik Laut China Selatan Tantangan Bagi ASEAN. Jakarta: Center For Strategic and International Studies, 1997.

Weingerl, Ales. "Definition of Unilateral Acts of States," n.d. http://www.esilsedi.eu/sites/default/files/Weingerl_0.PDF.

Yakin, A. Legal Research and Writing. Lexis Nexis, Kelana Jaya, 1992.

Zahraa, Mahdi. Research Methods for Law Postgraduate Overseas Student. Stiglow Sdn. Bhd. Kuala Lumpur, 1998. 